\title{
THE CHURCH AS THE MAKER OF CONSCIENCE.
}

"THE true and grand idea of a church," said Thomas Arnold, "is that of a society for making men like Christ, earth like heaven, and the kingdoms of this world the kingdom of God." Whatever concerns man concerns Jesus Christ; and whatever concerns the Master, it is evident, must concern those who call themselves disciples. Nothing that is common to man can be alien to the Christian.

A word of definition and explanation at the beginning may prevent misunderstanding at the conclusion. In considering the church as the maker of conscience, we do not mean to imply that this is all the work that the church has to do; we only maintain that this is an important and essential part of the church's work. There is the work of the church in evangelism; there is the work of the church in missionary extension; there is the work of the church as the leader of worship and the quickener of devotion. But, over and above this, there is the work of the church as the maker of conscience. This has to do with what may be called the prophetic, the ethical, the social work of the church. The word "conscience," as everyone knows, is used in a variety of senses, but these reduce themselves to two. The term "conscience" is here used to describe that power of the human soul by which man makes moral distinctions and guides his life. The conscience, in discovering to us the moral law which is to guide our lives, has authority over all the springs of action within. In speaking of conscience, we shall use the term in this larger sense : we shall consider the moral ideals and ethical principles which are discovered to the soul, and we shall consider the ratification and fulfilment of these ideals and principles by man himself. On the one side we have to do with the work of the church in the unveiling of the divine ideal of man and of society before men; and on the other side we have to do with the exposure of the human soul to this divine ideal, and the arousing of the human will to fulfil this ideal. 
I. THE WORK OF THE CHURCH IN THE MAKING OF CONSCIENCE.

The church we may define as the organized confession of the divine life in man. The state we may define briefly as the institute of right human relationships. The church, it is evident, has to do primarily with the inner life; its field of operation is in the realm of the affections, the reason, the will. By its teaching, its order, and its ordinances, it seeks to convince the reason, to stir the affections, and to persuade the will. In many ways this inner world is more important than the outer world: Out of the heart are the issues of life; as a man thinketh in his heart, so is he. The state, on the other hand, has to do primarily with the outer life; its field of operation is in the realm of acts, deportment, and institutions. By its organization, its machinery, its courts, it seeks to formulate laws, adjust relations, and determine conduct. In the last analysis government in a free republic is government by public opinion and social conscience. Thus the relation between the church and the state is very clear: the state, in its organization, its machinery, its laws, gives effect to public opinion; the church, in its order, its teaching, its discipline, creates public opinion. When the machinery of government is inefficient or corrupt; when the laws are inequitable and unrighteous, we know that the public opinion is weak and the social conscience is torpid. In no well-regulated state, least of all in a democratic state, can the civil statute rise much higher than the public conscience. And in the long run every conviction in the public conscience will find its way into the civil statute. Let me make the conscience of a people, and it matters little who make its laws.

The making of conscience is an essential part of the church's work. So far as one can see, there is no other institution so well qualified for this work. No other organization has the divine commission or the adequate machinery. The state cannot do this work, for government is itself a creature rather than a creator. The state is the organ of the political consciousness, and by its very existence it implies a consciousness lying back of its organization. The time is coming when the state will assume many functions that are now fulfilled by voluntary 
societies and private initiative, but the time will never come when this work of making conscience can safely be intrusted to the machinery of the state. For the state has to do with things as they are; the government attains its ends by compromise and expediency; political programs are concerned with the actualities rather than with the idealities of life. The political parties of the land cannot perform this work, for they have never yet been able to do more than keep themselves half respectable. Political parties are opportunists in the fullest sense of the word, and they give scant consideration to remote ideals. The measures that will win in the next campaign are the stock in trade of political parties. The practical politician is a rigid realist, and he sternly eschews the ideal. The political program that is popular today, the political measure that wins in the next campaign, may be utterly wrong when judged from the point of view of universal history; they may be little else than shameful betrayals of the highest and longest interests of humanity. The political parties of the land can never become safe trustees of the divine ideal or satisfactory exponents of the divine purpose.

The daily press cannot do this work, for the press is fast becoming an echo and not a voice. The average newspaper is the mouthpiece of a party, and it is pledged to make its partisan arguments appear the better reason. No man in his right mind goes to the partisan daily for a fair and generous discussion of the issues of the day. Then the average daily is published by a stock company, and dividends are the first consideration. Too often the counting-house end of the paper determines the editorial policy. There are newspapers in the land that are like the knight of old-sans peur et sans reproche-but the number of such is lamentably small. Several years ago an effort was made to secure the passage in the New York legislature of a bill requiring the inspection of stores and factories, that certain sanitary measures of the state might be made effective. The proposed bill was indorsed by many of the most conservative and prominent men of the state. The great dailies of the cities published articles and interviews adverse to the measure, but 
they failed to publish a line favorable to the bill. A friend of mine, in behalf of the friends of the measure, called upon the city editor of one of the leading dailies, a personal friend, and complained of the unfairness of all this, and asked only that a few interviews with himself or others be inserted. The city editor said that this was fair and right, and agreed to consult the editor-in-chief. In a little while he came back and said: "I have never been ashamed of the paper before, but I am heartily ashamed now. The counting-house end of the paper has informed the editorial department that this bill must be opposed. The bill is just and right, but we can do nothing."

The public schools cannot do this work except in an elementary and primitive way. The public school deals with intellect rather than with conscience, with knowledge rather than with ethics. Many are convinced that the public-school system is fulfilling but half its work in thus concerning itself almost exclusively with the intellect. There are certain great moral principles which underlie all life and conduct, and the school system that ignores these or minimizes these comes short of its full mission. But at the best the public school must deal with primary principles and can never concern itself with the great ideals and eternal principles of personal and social life. Nor can the various reform bodies and philanthropic agencies do this important work. As a rule, these societies are organized to prosecute some special reform, and they cannot teach all-around morality. One can easily name a dozen reforms that are greatly needed, but these reforms at the best are but parts of a larger whole. No single and isolated reform, however good, can transform the world and bring in the kingdom of God. These reform agencies are confessions that the consience of mankind is either ignorant or misdirected. A society organized for the purpose of pushing one particular reform is, by the very nature of the case, disqualified for the larger work of making an all-around conscience. This work must be done, and, so far as one can see, the church is the only organization in the world that has at once a divine warrant and a divine commission for this very work. 
II. THE CONSCIENCE TO BE MADE BY THE CHURCH.

I. First of all, the church, as a depository of the divine ideal, must set up an ideal, a standard of success; and must create a conscience which shall honor this standard and fulfil this ideal. The ideal is the truly real. The real never finds firm foundation for itself till it rests upon the ideal. It is the ideal that gives meaning to man's life and worth to his conduct. Ideals are the meat and drink of life. The ideal is more real and more important than the actual. "That which gives life its keynote," says a suggestive writer, "is not what men think good, but what they think best. The dominant influence of life lies ever in the unrealized. Not the criminal code, but the counsel of perfection, shows us what a nation is becoming." As everyone knows, there are certain ideals of life, certain standards of success, certain conceptions of duty, which prevail in our age and land. Many gospels are being preached in our day in newspapers and books, on the platform and in society - the gospel of wealth, the gospel of getting on, the gospel of success and glory - which are nothing less than false gospels. These gospels find appreciative hearers and easy acceptance, however, and they are in great vogue in our time. The world is very impatient with the man who discusses and criticises these gospels; but discussion and criticism were never more needed than today. And, popular or unpopular, this work must be done by the men who profess and call themselves followers of Christ and teachers of his gospel.

In season, out of season, the gospel of wealth is being preached, and rich men are being set up as teachers of the young and exemplars of the people. Let me say that I have no sympathy with the shallow and noisy demagogues who denounce rich men beause they happen to be rich. In themselves riches are neither bad nor good; and so the fact that a man is rich or poor says nothing concerning his moral worth or worthlessness. The money-making talent is one of the most useful of the gifts of God to the children of men, and this talent rightly used is productive of untold good in the world. We are not concerned here with the question whether these great riches are gained in loving and legitimate or unloving and illegitimate ways. We 
are concerned here merely with the effect upon the people of the gospel of wealth and the worship of rich men. ${ }^{x}$ In church and college, in society and in the press, rich men are honored and flattered, and are held up as models to be adored and imitated. The influence of all this, as anyone can see, is to degrade the common morals; it is to set up a false ideal of life ; it is to fire the imagination of the young with unholy and unworthy ambitions; it is to cast discredit upon the poorer and humbler workers in the kingdom of God. Every careful student of modern society declares that the reign of commercialism has come, and with the reign of this commercialism there has come a sad confusion of moral values. This commercialism places money above life and things before men. "Our whole society," says Felix Adler, "is infiltrated with the money-getting idea." There is danger lest a commercialism utterly destitute of moral and spiritual conceptions shall usurp the place which should be held by truer and Christlier ideals. Rich men have their place in the economy of life, and money has an important function to fulfil in the work of the kingdom. But money is not by any means the only thing worth while here below; nor are rich men the only men who have succeeded in life. "Thee must get rich my son," said the Quaker mother to her son; "thee must get rich honestly," so runs the story, "but thee must get rich."

Closely akin to this is another false ideal which is set up before the people for honor and imitation. As everyone knows, the military ideal has held sway for untold ages over the minds and hearts of men, and the great men of history are largely military leaders and conquerors. How far militarism is necessary in an imperfect and evolving society it does not concern us here to inquire. The military captain no doubt has had his work to do in the world, and let him have his wreath of laurel leaves. But the military ideal, it is needless to say, is not the Christian ideal, and the two can never be completely harmonized. Just now there is a recrudescence of militarism throughout the civilized world, and this bodes ill for the future. The heroism of the battlefield is a splendid thing; but no less splendid is the

"See editorial, "The Gospel of Wealth," in The Independent, May 30, 1901. 
heroism of the quiet life and the obscure duty. By all means give the military hero his due meed of praise, but, in the name of all that is highest and best in our civilization, do not make him the hero and exemplar of the people. One thing is clear: the church that preaches and promulgates these gospels of wealth and militarism is a moral and religious impertinence. The church that holds up before men the great ideals of Christ and his kingdom, and arouses the conscience of men to seek those ideals, shall save both itself and the world. The church must make men see that a man's life consisteth not in the abundance of the things which he possesseth. The church must make men know that one can be great and yet poor, and that there are attainments better worth while than millions of money and successes higher and truer than military fame.

2. The church must create a higher type of political obligation. In the providences of God we have become members of the democratic or free state. This means that ours is a government of the people, by the people, and for the people. All this, as anyone can see, implies and necessitates the ability of the people to govern themselves. Whatever restraints rest upon the people are self-imposed restraints. Popular government implies and necessitates the willingness of each man to subordinate his own preferences to the common good and to place the common weal before his own private wealth. Suppose the people become impatient of restraint? Suppose each man endeavors to make his own preferences the final law of conduct? In this case popular government is at an end, whatever may be the particular outward form of organization. In the last analysis popular government is government by public conscience. Suppose the people have no public conscience? Suppose the public conscience is misinformed or perverted? In this case the people are the dupes of demagogues and the prey of bosses.

The American people, one is ready to believe, have a very keen sense of personal integrity. They have also a very enlightened ecclesiastical conscience. They are very regardful of the higher proprieties of family and social life. They have a very deep sense of obligation toward the heathen peoples of the 
world. But have the American people a political conscience? Have they learned to bring all the questions of political and social life into the court of conscience and to try them there? Have they learned to interpret all the relations of their commercial and political life in the light of the Christian ideal and the Christian law? Here and there may be found a man who does this ; but as a people it can hardly be said that we have attained. The average citizen, so far as one can judge, has little more than a trace and rudiment of any such thing as a citizen's conscience. As a rule he belongs to a party, and he indorses its platform and supports its candidates. During a political campaign he becomes enthusiastic for the party's success and shouts the party's war-cries. But beyond this the average citizen has little interest in political affairs; beyond the success of his party he feels little responsibility for the doings of the government.

The so-called "best men" of a community are not always the best citizens. The jury system is the very bulwark of our Anglo-Saxon civilization; but on all sides one hears the complaint that the jury system is a failure. This complaint comes, not alone from the malcontents and pessimists, but from the calmest and most intelligent minds of the land. This failure, so far as there is failure, grows out of the unwillingness of good men to perform jury duty. Men are so busy with their moneygetting and pleasure-hunting that they have no time to fulfil the first duty of citizens. On the other hand, there is always a crowd of courthouse parasites and party leeches who say: "Put me on the jury lists that I may earn my little dollar."

The American people have too little confidence in one another's political sincerity. Let a man arise in any community and take a citizen's interest in the affairs of state, and at once the rank and file of men will declare that he is a self-seeker and place-hunter. It must be confessed that the faith faculty of the people has been sorely tried in past years. They have been betrayed so often that it is little wonder they should be skeptical. That brazen-faced and unscrupulous men should force their way to the front and intrigue for office is not surprising in this world of fallen man. That certain moneyed 
interests should cajole, intimidate, or buy legislators is not at all strange. That certain black-hearted bosses should use the machinery of government to perpetuate their own power and further their own interests is not unexpected. The Judas taint is in the blood of our humanity, and there is always an Iscariot to betray the sons of men. But that the people should be satisfied to have it so; that they should feel no shame in the presence of these things; that they should fall into line and accept the bosses' yoke-this passes comprehension. The people do not expect an unselfish citizenship on the part of their political leaders; and this means that the people do not expect an unselfish citizenship of themselves. This is the most ominous sign of the times in American political life. Men do not expect an unselfish and disinterested citizenship of themselves or of one another; in a word, they have little sense of political obligation and public duty.

As everyone knows, a double standard of morality prevails, and men have one kind of right for their personal and family lives, and a different kind of right for their political and commercial lives. All such things as sentiment, conscience, and love are ruled out of politics, and we are told that the Decalogue and the Sermon on the Mount have nothing to do with a political campaign. English history records that Charles I. endeavored to save Strafford, his agent, but he wished also to please the people, who demanded his death. The good bishops of the time solved the king's perplexity by advising him that " a king has two consciences, one public and the other private; and that his public conscience as a king might not only dispense with, but oblige him to do, that which was against his conscience as a man." The chancellor of the German empire has lately declared: "I cannot conduct foreign policy from the point of view of pure moral philosophy. It is not ours to ask what is right and what is wrong. The politician is no judge of morals ; he has solely to maintain the interests and rights of his country." Another man, not himself a practical politician, but a political philosopher, Professor Willoughby, declares: "It is, in fact, quite superfluous to show in this age that from their own inherent 
nature divine and moral sanctions can have no application to political matters." - So long as such sentiments prevail in high places, it is not surprising that they should appear in low places. And so long as such sentiments prevail, whether in high places or in low, that long the church of Jesus Christ will have a most fiery and relentless mission.

On many questions of public policy there is a wide and wise difference of opinion. Whether the state should own and operate all the means of communication and transportation; whether the state should manage and own all natural monopolies - these are open and moot questions. But that our city governments should do many things that are now done by private individuals or are not done at all; that our state governments should assume many new functions - all this is pretty well admitted by careful and informed thinkers. Yet one hesitates to advocate these things for the simple reason that the government is not ready to undertake them. On all sides we hear the cry that government cannot do these things; that government management means waste, inefficiency, and corruption; that these things must be left to private initiative and control. This is a most pitiful confession, that the people cannot be trusted; this means that men will not put forth their best efforts unless they are motived by the hope of private gain; this means that men who are regardful of their private interests are indifferent to the public welfare. That there is work for the churches to do in creating a sense of political obligation must be evident to every right-minded man.

3. The church must create a conscience that shall move men to arise and build a higher and more Christian type of human society. Christianity has proved its ability to create the finest type of personal piety; it has created the Christian home, one of the most splendid achievements; it has created also the Christian church, the household of faith and love. No one who understands history will be inclined to make light of these great gesta Christi. But all these things do not exhaust the Christian's calling. The Christian disciple, in occidental lands at least, finds himself a sovereign in a free state, and as a consequence his conscience is burdened with new obligations, and 
his will is confronted with new tasks. The Christian spirit is now engaged in the work of creating citizens who shall bear the burden and heat of the state's struggle for life and progress. Once the Christian ideal created saints who lived withdrawn from the world's trade and politics, with little stake, so far as conscience was concerned, in the world's life. The Christian spirit must still create saints, as Professor Nash suggests, but these saints must learn to live their deepest and truest life amid the' masterful organizations of society, and they must learn to fulfil the claim of conscience in the wide realms of political and social service.

In our time the power of Christianity is to be proved by its ability to create a Christian type of human society. Society as it exists today is made up of rich and poor, of cultured and ignorant, of the strong and the weak, the competent and qualified and the defective and delinquent, the saint and the criminal. It is not the will of the Father in heaven that one of his little ones should perish. It is intolerable to all right religion that numbers of people should be miserable and needy while there is plenty and to spare in the Father's house. No one who believes in Jesus Christ can believe that it is the will of the heavenly Father that one part of the human family shall go hungry and destitute while another part is living in luxury and ease. The most tragic fact about this poverty and ignorance is not the hunger and suffering, though these are sad enough. The saddest feature about it all is the waste of human life, the fact that the wonderful possibilities in these human brothers are never unfolded and realized. A social and industrial system in which one man controls thousands of lives and is possessed of millions of money; in which able-bodied men willing to work walk the streets in desperation looking for a job; in which thousands of women, owing to oppressive labor and small remuneration, are under a continual temptation to barter womanhood for gain; in which are tenements not fit for pig-sties where women fight with fever, and infants pant for air and wail out their little lives; in which the sweater's den and the grog-shop thrive-such a society is very far, indeed, from that order which God wishes 
and ordains. Contentment with things as they are is treason to the divine ideal. To fold our hands and do nothing ourselves in the presence of these things is to doom ourselves to the outer darkness and the bottomless pit.

III. THE METHOD OF THE CHURCH IN THE MAKING OF CONSCIENCE.

Every problem is an opportunity. The modern world is full of urgent and clamant problems which must be solved, or our civilization will pay the forfeit. Every one of these problems has a moral and spiritual aspect : at bottom they are all religious questions. "Omnia exeunt in theologiam." Hence it is that every problem of man and of society vitally concerns the church of Jesus Christ. There are four ways in which the church may serve the world as the maker of conscience.

I. The church in its life and order must witness for the divine ideal and the divine law. The church is that part of God's universe which has come to self-consciousness and selfrealization. Hence the church is here to stand forth as the living witness for the will and truth of God. And so the church is here to interpret God to man, and man to himself. The church is here to reveal the ties that bind men together, and to be the living witness for the law of the spirit of life in Christ Jesus.

The church of the living God is a family, and its members are all brothers. Out in the world all kinds of divisions and rivalries separate men, and the bond of brotherhood is either denied or ignored. Men are separated by the barriers of class and condition, of wealth and social position, of culture and pedigree. Now, right in the midst of all these warring factions we find a company of men who by their very organization and life witness to the great and vital Christian truth of brotherhood and love. The two universal ordinances of the church are perpetual witnesses to the unity of mankind. Baptism, on its human and social side, is a declaration to the world of the solidarity of the race. "For as many of you as were baptized into Christ did put on Christ. There can be neither Jew nor Greek; 
there can be neither bond nor free; there can be no male and female; for ye are all one man in Christ Jesus.' The Lord's Supper, the other ordinance of the church, is even more plain in its testimony. This simple ceremony of breaking bread together testifies forever to the precious truth that we are all brothers, children of the one heavenly Father. The church is not a company of elder brothers to be feasted and petted, but a family circle in which the strong tarry for the weak and the highest serve the lowest. At this table prince and peasant are equals, the millionaire is the brother of the journeyman, and the scholar is the fellow and friend of the laborer. Not always have these larger, human, social aspects of these ordinances been recognized. But these ordinances, rightly understood and fulfilled, can do much to witness for God's order and to create a conscience in mankind.

2. The church in its work of teaching and testimony can do much to inform and arouse the conscience. The church must make men know what is the good and acceptable and perfect will of God; and it must teach men how to apply that knowledge to everyday life. The church must make men know what are the relations in which they should live with one another. It must make men know what are the things that mar fellowship and hurt society; and it must make men know what are the things that promote fellowship and strengthen society. If industrial conditions are unjust, unfraternal, and depressing, the church must know it and must plead for better conditions. If society is divided up into classes and parties, the church must know it and must bear witness for fraternity and unity. If the rich and powerful oppress and wrong the weak and poor, the church must know it and must rebuke the oppressors and must right the wrongs. The churches must set their faces like a flint against everything that hurts man, that mars fellowship, and divides society. The churches must bear unfaltering testimony for righteousness and love, for fraternity and justice.

In the church is the pulpit, the recognized leader and teacher of the people. It will probably be admitted by all that the preacher is a prophet, and is called to be the representative 
of God's order and will. Back of every problem in society is a sin of man. The statesman's skill must ever be supplemented by the prophet's conscience. We must never forget that sin does not manifest itself alone in the hearts of men, but that it may embody itself in wrong sentiments and unrighteous customs. Every age and place has its peculiar sins and needs, and men must be convicted of sin along the line of their characteristic sinning. The preacher is tempted to deal lightly with these popular sins, lest antagonism be aroused and the income of the church be affected. Today, as of old, there are men who resent the prophet's stern demand for righteousness and his calm criticism of their sins. The preacher may discuss forever the sins and idolatries of the long-dead Hebrews; but let him seek to make his message real and apply the truth of God to the social vices and idolatrous practices of his day and community, and at once many voices will be heard in protest. Many will affirm, in fact, that he is cheapening the gospel in bringing it down to date in this real and practical way. The preacher is thus under a continual temptation to deal in generalities so vague and indefinite that men guilty of all kinds of wrongs escape with heart untroubled and conscience unscathed.

It may be replied that preaching on these things is hazardous. That may be; but hazardous to whom? To the preacher? All the real hazard to him arises from the fact that he is faithless to his trust. To the hearers? Would to God that it were more hazardous to those who are guilty of the monstrous wrongs which hurt their fellows and hinder the kingdom of God! Put Isaiah or Jeremiah, James or John, down in a Christian pulpit in a modern city, and what would be the burden of their message? For one thing, be sure they would raise their voices like a trumpet and would cast into the face of a dilettante church the lost children of the people who curse and sin and die in filthy tenements paying 20 per cent.; in words that would scorch and burn they would arraign some of our social crimes, our industrial practices, our political treasons; they would expose some of our modern covenants with death, and would denounce some of our agreements with hell. "If I were preaching in Westminster 
Abbey," said Coleridge, "I would say nothing about smuggling ; but if I were preaching in a village of wreckers on the coast, see if I would preach about anything else."

The preacher is not here to preach ethics or sociology; he is not here to preach on the rights of labor or the rights of capital; he has nothing to do with the platforms of parties and the programs of reformers. But he is here to witness for righteousness and love in all the relations of life; he is here to show laborers and capitalists that they are brothers and partners; he is here to create the conscience which shall make all right laws and statutes. He cannot shirk this work and be true to God and man. The preacher is not sent to preach sociology and ethics; but neither is he sent to preach a creed or a theology. But as we insist that the men who are to be the prophets of God and the teachers of the people shall know theology, so we must insist that these prophets and teachers shall know sociology. The preacher has nothing to do with the platforms of parties and the programs of reformers; and, as a rule, he weakens his influence when he meddles with these things; but he has everything to do with the conscience that lies back of platforms and finds expression in programs. The state is called to give effect to public opinion and the social will; the church is called to create public opinion and determine the social will.

3. The church can do much to create a right conscience by maintaining a Christian discipline. Thus far in the history of the church discipline has been very lax and very partial. Certain branches of the church universal have wielded the rod of doctrinal discipline; and certain branches have drawn the lines of discipline at ritualistic laxity; and still other churches have disciplined members for frivolity and worldliness. Thus far in the history of the modern church little attention has been paid to questions of social injustice, of political unrighteousness, of commercial cruelty. These first-named things the churches should no doubt have done; but the last-named things they should not have left undone. In some churches men are disciplined today for heretical opinions concerning the Scriptures or the Trinity; in some other churches men are disciplined for 
dancing and card-playing. But who ever heard of a church member being disciplined for political crookedness and commercial inhumanity? The fact is, as everyone knows, some of the men guilty of these political treasons and industrial cruelties are members of Christian churches in good and regular standing. Men are disciplined, and rightly, for drunkenness; but who ever heard of a prominent church member being disciplined for gambling in breadstuffs or corrupting a legislature? A church is a company of men and women who have Christ's passion for righteousness and truth. A church that is fulfilling its mission in the world is creating a moral and a spiritual atmosphere; that atmosphere must be so intense that the evil-doer will either be melted and brought to repentance, or he will be scorched and made to exclude himself. In every Christian church there ought to be an atmosphere so intense, a sentiment so strong, a passion for righteousness so deep, that the political curruptionist and commercial sharper should be compelled to amend his ways or surrender his membership. The church that fails to rebuke sin, whether in high or low, whether popular or unpopular, fails in its duty to God and to man. "Salt is good; but if the salt have lost its saltness, wherewith shall it be salted? It is thenceforth good for nothing but to be cast out and to be trodden under the feet of men." The church must testify as did Nathan before David: "Thou art the man." The church must testify as did John the Baptist before King Herod: "It is not lawful for thee to have thy brother's wife." The church must testify as did Paul before Felix when he reasoned of righteousness, temperance, and judgment to come. The church must testify as did Ambrose of Milan when he stood before the cathedral door and drove back the emperor Theodosius when he came red-handed from the slaughter of the Thessalonians. The church must testify as did Savonarola when he refused to absolve Lorenzo de Medici unless he gave up his tyranny and set Florence free. Woe to the church that is seeking to keep on good terms with an unbelieving world! And woe to the church that cries Peace, Peace, when there is no peace!

4. And last of all, and as the summing up of all, the church 
must hold up before men the Christian ideal of human life and human society. In the book of the Revelation we are given the picture of a holy city coming down from God out of heaven, a city in which man dwells in perfect peace and security, a city into which nothing enters that defiles, that works abomination, or makes a lie. What is the meaning of that vision? Are men given this vision that they may admire the beauties of the holy city, that they may discuss its government and argue about its geography? Nay, not so; rather that holy city is the divine model after which men are to build these cities on earth. Men believe in a holy city, a city of God, into which nothing enters that defiles, that works abomination, or makes a lie; a city in which man dwells in righteousness and peace; a city in which all are fed and all are blessed. Then it is their business to arise and build a city on earth according to the divine pattern; it is their business to cast out of the cities of earth the things that defile and make a lie; it is their business to build a city that shall be the human realization of the divine ideal.

The Christian ideal fairly and fully commits us to the work of creating a higher and diviner type of human society. And the mind of Christ calls for a generation of men who will put themselves and their profession in pledge in behalf of this higher and diviner type of society. Let this Christian ideal be seen in all its power and beauty, and several things will follow. For one thing, all who call themselves Christians will feel themselves and their profession steadily put to shame so long as a single wrong tarries in society and a single soul is without true inheritance in the world. For another thing, the conscience of the Christian discipleship will feel itself charged with the welfare of the downmost man, and it will find no peace till it has gone forth in a missionary effort in his behalf. The Christian's whole ideal and creed is at stake so long as a single soul is ignorant and a single corner of society degraded. "This is the thing that Christianity must do in order to carry off from the great debate of comparative religions the prize of the world's allegiance." $x$ Under the sway of this Christian ideal men will feel a new responsibility for the welfare of the weakest and lowliest man, and they will

${ }^{2}$ Professor NASH, Ethics and Revelation, p. 167. 
seek to bring the highest good within the reach of this man, and to lift him up into the appreciation of his manhood's glory. Under the sway of this Christian conscience the Christian disciple will suffer a new conviction of sin so long as there is an unprivileged life in the community. He will feel under obligation, not only to help the beaten and incompetent, but also to remove the causes which weaken and defeat men. He will feel the degradation of the delinquent brother as his own burden and shame, and he will see that his own profession is steadily put to shame so long as there are delinquent and defective classes. A church that is fully conscious of its mission will realize that it is called to make and shape the conscience of the community. So long as a wrong tarries in the community, so long as stumblingblocks are placed before men, that long the church must search men through and through with the merciless fire of self-examination. We are our brother's keeper, and the conscience of men must be charged with the brother's keeping in all the relations of life.

The mission of the church is evident; the church's credentials are clear; the need of the world is great. Nothing could be more weak and pitiful than for the churches to confess that whole provinces of life lie beyond their interest. Nothing could be more cruel and cowardly than for the churches to say that they have no word to offer on the problems which make the peril and the opportunity of our time. Nothing could be more calamitous and short-sighted than for the churches to leave to outsiders, to unbelievers often, the discussion of current wrongs and the leadership in moral reform. Not for a moment would we have the churches become mere humanitarian and reforming agencies. But not for a moment would we have the churches neglect this work as beneath their notice. "The God that answereth by orphanages," said Mr. Spurgeon to the scoffers, "let him be God." A religion that is out-humaned by the humanitarians is not the religion of the Son of man. The churches must enter into the mission of the Son of man: then they can go forth to assume the leadership of the social faith and to be the maker of the world's conscience.

Samuel Zane Batten.

MORRISTOWN, N. J. 